\title{
APPROACHING ERASMUS STUDENTS' INTERCULTURAL COMMUNICATIVE COMPETENCE THROUGH THEIR SOCIALISATION PATTERNS
}

\author{
Gloria Gutiérrez Almarza \\ Nottingham Trent University \\ gloria.gutierrez@ntu.ac.uk \\ RAMiro Durán MarTínez \\ University of Salamanca \\ rduran@usal.es \\ Fernando BeLtrán Llavador \\ University of Salamanca \\ fdob@usal.es
}

\begin{abstract}
This paper presents a qualitative analysis of the impact of university students' socialisation patterns on the development of ICC (Intercultural Communicative Competence) during their Erasmus placements. In our research, we complement previous comparative analyses of a quantitative nature between UK and Spain based students' ICC. The answers to sixteen items from a questionnaire provided by 40 Nottingham Trent University and 30 University of Salamanca students shed light on three pivotal dimensions: everyday interaction patterns, overall perception of the study sojourn, and intercultural lessons learned during their stay. Our results show that, at the end of their placement, both cohorts report no substantial differences on their means to socialise while abroad and that the two confer paramount importance to being open-minded and using the target language proficiently, while their perception differs regarding aspects such as their previous knowledge about the host country or their self-image as representatives of their home culture.
\end{abstract}

Keywords: Erasmus, Intercultural Communicative Competence, Intercultural Education, Higher Education, Socialisation, Study Abroad. 


\title{
UNA APROXIMACIÓN A LA COMPETENCIA COMUNICATIVA INTERCULTURAL DE LOS ESTUDIANTES ERASMUS A TRAVÉS DE SUS PATRONES DE SOCIALIZACIÓN
}

\begin{abstract}
RESUMEN. Este artículo presenta un análisis cualitativo del impacto de los modelos de socialización de estudiantes universitarios en el desarrollo de su CCI (Competencia Comunicativa Intercultural) durante su estancia Erasmus. Esta investigación complementa análisis cuantitativos previos que comparaban la CCI de estudiantes de España y del Reino Unido. Las respuestas de 40 estudiantes de Nottingham Trent University y 30 de la Universidad de Salamanca a los dieciséis items del cuestionario abordan tres dimensiones: patrones cotidianos de interacción, percepción general de su estancia Erasmus y lecciones interculturales aprendidas. Nuestros resultados muestran que, al finalizar su estancia, los dos grupos no evidencian diferencias sustanciales en sus formas de socialización en el extranjero y conceden primordial importancia a mostrar una actitud abierta y al dominio de la segunda lengua. Sin embargo, sus percepciones difieren en aspectos como su conocimiento previo del país anfitrión o su imagen como representantes de la cultura de su país.
\end{abstract}

Palabras clave: Erasmus, competencia comunicativa intercultural, educación intercultural, educación superior, socialización, estudios en el extranjero.

Received 22 March 2017

Revised version accepted 7 July 2017

\section{INTRODUCTION}

A communicative landscape of linguistic complexity where English undisputedly acts as the lingua franca par excellence (Baker 2016) and a worldwide increase of mobility are causing an unprecedented shift in language teaching that involves the need to "transcend the traditional paradigm of one nation, one language, one culture" (Risager 2016: 48). Added to that is a steady growth in the number of students who follow tertiary education abroad, which is also intensifying the need to foster intercultural communicative competence (henceforward ICC) development schemes to optimize rather than just "cope with" cultural encounters. Significantly, the Erasmus + (European Region Action Scheme for the Mobility of University Students) budget of over 14 billion includes funding for more than 2 million university students to study and 800.000 lecturers, teachers, trainers, education staff and youth workers to teach or train across Europe during the 2014-2020 period (European Commission 2015). However, this should not belittle the relevance granted today to ICC beyond the European region, as reflected in studies from and about other areas of the globe (Deardorff 2009). 
APPROACHING ERASMUS STUDENTS' INTERCULTURAL COMMUNICATIVE COMPETENCE THROUGH THEIR ...

This paper presents a work in progress following an investigation on the impact that university students' Erasmus placements may have on the development of their ICC during their residence abroad (Gutiérrez, Durán and Beltrán 2015; Durán, Gutiérrez, Beltrán and Martínez 2016). Our previous comparative analyses of the impact of such placements on UK and Spain based students' ICC showed that, on completion of their stay abroad, the two cohorts subject to scrutiny had gained a greater sense of ICC even if noteworthy differences between them emerged. At the end of their placement, UK Nottingham Trent University (NTU) students claimed to have achieved greater knowledge of their host country as well as an increased critical awareness while no particular impact was reported regarding their attitude and skills. However, their Spain University of Salamanca (USAL) counterparts exhibited a slightly less positive attitude than that reflected prior to their experience abroad even when their perceived development of the dimensions of awareness, knowledge and skills was also significant.

\section{THEORETICAL BACKGROUND}

In previous publications we discussed some of the different understandings of ICC (Gutiérrez, Durán and Beltrán 2015; Durán et al. 2016), particularly the one articulated by Michael Byram (1997, 2012), on whose model we have based the main analysis of our data. We argued then that the target culture acts as a mirror, which helps students not only to perceive their own cultural identity from a different perspective but also to gain a fresh awareness of the ways in which speakers of the target language may perceive them. In consonance with Byram (2000), we also claimed that this awareness is the condition on which they will be able to build new knowledge, change attitudes and develop ICC skills. Through a process of self and others discovery, by uncovering their behaviour in the face of otherness and thus being open to the identities and cultures of the people they interact with, and therefore by using culture as a tool for self-refection on their own cultural background and by collaborating with others, learners may become intercultural speakers (Byram and Zarate 1997; Sáez-Hidalgo and Filardo-Llamas 2014; Baker 2016) and even get involved in multicultural teamwork (Méndez and Pérez 2011). This new learning horizon may provide learners with a more balanced relationship in their interaction with speakers of languages other than their own.

Relating one's culture, or constellation of cultures, to the host's demands a readiness to reflect, confront oneself and above all, to play a mediating role between both, and indeed to change (Risager 1998). This change or intercultural learning, however, "can only be grasped by inferring it from changes in people's behaviours" (Borghetti, Beaven and Pugliese 2015: 44). In short, gaining awareness 
of their own identity and the way members of their new cultural milieu perceive them "will help students to explain and accept differences but also to accept that these differences are never permanent or static" (Durán et al. 2016: 3).

Following Dervin (2007, 2011), we would now like to add to previous conceptualisations the notion of "liquidity", which has been studied from a sociological perspective with reference to that which is not given enough time to solidify, whether it is time itself, identity, population sectors, or society at large (Bauman 2007). Dervin's contention is that, as an attribute, "liquid" is also applicable to the experience of Erasmus students, given the temporary status of their tertiary studies' placement in a foreign country. For this reason, besides proposing "a liquid approach to intercultural discourses" (Dervin 2011), he regards Erasmus students as archetypal "liquid strangers" who, as a way of developing their intercultural competence, should be given "the opportunity to look at themselves and others, as well as reflect on their own discourse and attitudes" (Dervin 2007). By doing so the ground will be paved for them to become more than mere carbon copies of native speakers.

This paradigm shift opens for us the possibility to see and explore their stay abroad as taking place in a third space (Smolcic 2013: 95) where new interpersonal and intercultural realities emerge that need to be constructed and negotiated, as they cannot be fully identified with either the native or the target cultures. It is by means of everyday interaction patterns, which are the focus of our research, in their communities of practice (Bracke and Aguerre 2015) that students develop and give way to novel intercultural domains and spheres of relatedness which constitute the "threads" (Holliday 2016: 320) or fabric of a symbolic realm where the subject "is never finished, it is always in construction", in other words, "a work in progress" (Kramsch 2009: 96).

Seminal research on student mobility (Beaven 2012; Beaven and Borghetti 2016) and pedagogical proposals to foster ICC processes before and during the year abroad (Penman and Ratz 2015) have also been an inspiration for our own paper, even if we did not seek to provide a fine-grained depiction similar to that of studies like the ones carried out by McManus, Mitchell and Tracy-Ventura (2014) on the study-abroad experience of English-speaking sojourners in France. Our findings, however, both complement and nuance the results of our previous research while throwing further light on aspects such as the prevalent activities students engage in and the language they resort to for diverse social interactions (Gautier and Chevrot 2015; Teichler 2015).

Social networks doubtlessly play a seminal role in the plethora of interactions and learning outcomes of study abroad and, since they are usually formed early, they may remain stagnant or develop. They do "represent a major influence on the 
APPROACHING ERASMUS STUDENTS' INTERCULTURAL COMMUNICATIVE COMPETENCE THROUGH THEIR ...

variability of study abroad experience", to the extent that "[g]reater contact with the local community leads to greater gains. Interacting with host nationals has been shown to be a key to successful adjustment" (Coleman 2015: 52). Seen in this light, our study may nourish the very body of thinking that sustains it while it lends itself to yet prospective incursions into the kinds of personal drives, institutional guidance, and in situ social engagements that can lead to students' development of ICC.

\section{THE STUDY}

\subsection{AIM}

Our study aims to identify the socialisation patterns of UK and Spain based Erasmus students through their answers to sixteen items from a questionnaire (adapted from Buynsters 2012) which addresses three broad categories of ICC issues, namely, students' interaction patterns, self and other perceptions, and intercultural lessons, or conclusions, drawn from their experience of temporary mobility, all of which comprise more specific aspects such as language use, type of contact kept by participants with family and friends at home, and the activities they were involved in during their placement abroad.

\subsection{METHODOLOGY}

This research uses a mixed-method approach combining statistical data from the questionnaire with qualitative findings on the students' return to their home institution. A SPSS (23.0) tool for Descriptive Statistics was used, which allowed us to map the data and synthesize the answers of the questionnaire through tables so as to highlight the most salient results after a calculation of the standard measures of the central tendencies (mean) and of dispersion (standard deviation).

Additionally, we applied three complementary statistical analyses, namely, T student to find general differences between NTU and USAL students, which in fact yielded seemingly scarce yet relevant information, as will be shown later; $\mathrm{T}$ student to compare the results of NTU and USAL students in light of their previous experience, or lack of experience, abroad; and $\mathrm{T}$ student to compare where NTU and USAL students also differ significantly after considering the variable of whether they study a third additional language besides Spanish, in the case of NTU students, or English, in the case of their USAL counterparts.

The questionnaire contains a five-point Likert scale ( $1=$ the least frequent, $5=$ the most frequent). Besides gathering basic contextual information on students (age, gender, language level, languages other than L2, and previous experience abroad) 
it comprises sixteen items divided into three sets. Seven items focus on patterns of interaction, five on their self-perceptions, general impressions and feelings regarding their home and host countries, and four on their ICC findings about what they regarded as most relevant during their time abroad.

The questionnaire was distributed to two groups of students participating in the exchange programmes, one from the USAL, that was placed in British universities, and the second from the NTU, hosted by diverse Spanish universities during 2013/2014. A total number of 70 students (40 NTU and 30 USAL) completed it in September of the year 2014, shortly after their return from their placement abroad.

Evidence from students' oral reports on their experience abroad gathered from a total of 10 interviews ( 5 to NTU and 5 to USAL students) on return to their home institutions complements the quantitative findings.

\subsection{RESEARCH SUBJECTS}

NTU third-year students of Spanish and USAL third- and fourth-year students of English from the English Studies and the Primary English Language Teaching degrees filled the questionnaire. Thus, the two cohorts of students share the fact that they were taking degrees in either Spanish or English as a foreign language, yet two distinct traits regarding participation requirements and expected outcomes need to be considered for they provide relevant background information that should inform the reading of the data. Firstly, while NTU students are assigned a placement abroad as an integral part of their course regardless of their grades, USAL candidates are awarded study grants on the basis of their academic records, since the provision of places is limited. Secondly, regarding their academic expectations, whereas USAL students have to bring back credits of which they will be assessed as a component of their degree, NTU participants in the Erasmus programme are also required to complete credits and take exams but passing them is not an academic obligation.

Since there is only a slight age difference between the two groups, NTU students being 23.2 years old on average and their USAL counterparts 22.2, the age variable does not have a significant impact on the data. As for their gender, our study confirms that the study abroad is still, since its very inception, a markedly gendered experience closely bound to other identity issues (Kinginger 2009, 2015). In both groups most students are female even if there is, again, a slight difference between the two, for while in our sample there was a $67 \%$ of NTU female students, only $13 \%$ of USAL students are male.

The percentage of NTU students who had already stayed in the target country before their Erasmus placement for a period of over a month (72\%) is remarkably 
APPROACHING ERASMUS STUDENTS' INTERCULTURAL COMMUNICATIVE COMPETENCE THROUGH THEIR ...

similar to that of Coleman's (1998) sample of British students almost twenty years ago, while the figures are just the opposite in the case of USAL students, for $74 \%$ of whom this mobility programme was their first experience abroad.

\section{RESULTS}

The following three tables provide a synthesis of the answers to the questionnaire that asked students to rank the three main dimensions of their everyday Erasmus experience under the headings of (everyday) "interaction patterns", "perceptions" (of their experience abroad), and "intercultural lessons" (learned during their stay).

Table 1. Everyday Interactions. Percentage of frequency of NTU and USAL students' interactions during their Erasmus experience (NTU n=40, USAL n=30)

\begin{tabular}{|c|c|c|c|c|c|c|c|c|}
\hline & NAT & 1 & 2 & 3 & 4 & 5 & Average & $\begin{array}{l}\text { Standard } \\
\text { Deviation }\end{array}$ \\
\hline \multirow{2}{*}{$\begin{array}{l}\text { 1. I have made many } \\
\text { friends during my stay and } \\
\text { with most of them I will } \\
\text { definitely keep in contact } \\
\text { or even invite to visit me in } \\
\text { my home country }\end{array}$} & NTU & 0 & 2,5 & 20 & 25 & 52,5 & 4.28 & ,877 \\
\hline & USAL & 0 & 0 & 26.7 & 26.7 & 46.7 & 4.20 &, 847 \\
\hline \multirow{2}{*}{$\begin{array}{l}\text { 2. I keep an intense } \\
\text { interaction with family and } \\
\text { friends at home via Skype, } \\
\text { Facebook, etc. }\end{array}$} & NTU & 2.6 & 15.4 & 30.8 & 25.6 & 25.6 & 3.56 & 1.119 \\
\hline & USAL & 0 & 13.3 & 20 & 26.7 & 40 & 3.93 & 1.081 \\
\hline \multirow{2}{*}{$\begin{array}{l}\text { 3. I speak in target language } \\
\text { most part of the day }\end{array}$} & NTU & 0 & 7.5 & 27.5 & 37.5 & 27.5 & 3.85 & ,921 \\
\hline & USAL & 0 & 6.7 & 53.3 & 13.3 & 26.7 & 3.60 & ,968 \\
\hline \multirow{2}{*}{$\begin{array}{l}\text { 4. After classes/work, I } \\
\text { frequently participate in } \\
\text { other activities }\end{array}$} & NTU & 0 & 15 & 35 & 27.5 & 22.5 & 3.58 & 1.010 \\
\hline & USAL & 0 & 20 & 46.7 & 20 & 13.3 & 3.27 & ,944 \\
\hline \multirow{2}{*}{$\begin{array}{l}\text { 5. I prefer to be surrounded } \\
\text { by students of the Erasmus } \\
\text { exchange program, as } \\
\text { opposed to the local } \\
\text { students }\end{array}$} & NTU & 17.5 & 17.5 & 35 & 20 & 10 & 2.67 & 1.028 \\
\hline & USAL & 13.3 & 26.7 & 46.7 & 6.7 & 6.7 & 2.88 & 1.223 \\
\hline \multirow{2}{*}{$\begin{array}{l}\text { 6. When I go out, it is } \\
\text { mainly with people from } \\
\text { my own country/language }\end{array}$} & NTU & 15 & 27.5 & 35 & 20 & 2.5 & 2.68 &, 847 \\
\hline & USAL & 13.3 & 26.7 & 36.7 & 20 & 3.3 & 2.73 & 191 \\
\hline \multirow{2}{*}{$\begin{array}{l}\text { 7. I share accommodation } \\
\text { with people that speak my } \\
\text { language }\end{array}$} & NTU & 32.5 & 7.5 & 17.5 & 30 & 12.5 & 1.48 &, 234 \\
\hline & USAL & 40 & 20 & 20 & 13.3 & 6.7 & 1.31 & ,239 \\
\hline
\end{tabular}


Table 1 displays the data drawn from the answers given to 7 items (hereafter identified parenthetically as "i-") that describe the most salient patterns of social interaction, which have been ranked according to their frequency from the most (i-1) to the least rated (i-7).

What can be noticed from a general overview of this table is that the first and, hence, the most highly valued item concerns forging long term relationships with students from other countries and expressing willingness to keep in touch and to visit each other in their home countries in the future (i-1): NTU 4.28 vs USAL 4.20. More than half of NTU students assigned this item the maximum rating within the Likert scale. As for USAL students, 100\% of their answers are positioned between number 3 (positive) and 5 (the most positive value on the scale). This item does not show any significant difference between the two groups of Erasmus students. The way the two groups reflect their intense combined feelings of personal bonding and longing can be graphically summed up in the testimonies of NTU student 3 ("I have made lifelong lasting friends") and USAL student 4 ("I have just returned from the UK and I already feel sad because I miss the friends I have made there").

While they express their readiness to establish new relationships in the host country, students are nonetheless almost equally keen to keep in touch with their home country (i-2), which is slightly more noticeable in the case of USAL students: USAL 3.93 vs NTU 3.53. Thus, USAL student 3, like her fellow recipients of the mobility grant, took for granted that communication with her family on a daily basis was, unquestionably, the thing to do: "Yes, of course, I used Skype to communicate with my family in Spain on a daily basis while in England". The almost permanent online connection of higher education sojourners with their kin at home has been likened to attaching "an electronic umbilical cord of computermediated communication” (Kinginger 2009: 149).

The table shows that speaking in the target language most of the day (i-3) is also highly ranked, by the two cohorts of participants, with an average score just slightly below item 2 (USAL 3.85; NTU 3.60), and even above the preceding item (i-2) in the case of NTU students. This is consistent with item 7, which reveals that neither group tends to share accommodation with speakers of their own language (USAL 1.48; NTU 1.31). In the formulation of item 7 , which in principle should have been dichotomic, we took into account that students may change their accommodation and the fact that there are occasions when Erasmus students may share lodgings with speakers of different languages. The following comments make it evident that students' communicative scenarios may appear under many different guises and their interactions can be subject to manifold combinations. Thus, USAL student 4 uses English as a lingua franca ("I speak to my flatmates 
APPROACHING ERASMUS STUDENTS' INTERCULTURAL COMMUNICATIVE COMPETENCE THROUGH THEIR ...

in English every day. They are Chinese. I usually go out with Italian and French friends. We speak in English to understand each other"), while NTU student 5 was glad to "live with two Spanish students" and "hang out with them most of the time. I only spoke English with my parents".

Item 4 shows the shared commitment of both groups of students to make the most of their placement by engaging in different activities. Thus, they mention that after their academic chores they often participate in activities such as sports, discussion groups, student organizations, or going to the cinema or the gym. This item is slightly more highly scored by NTU students (NTU 3.58 vs USAL 3.27). The following snapshots offer a few glimpses of the above: NTU student 1 likes cooking, and, while in Spain, she seemed enthusiastic about the possibilities this offered to her: "I got hooked to Spanish cooking". As for NTU student 2, she conveyed a sense of achievement in bringing together a personal connection and a way of improving her language skills: "I have made a friend, and we meet once a week to exchange conversations in English and in Spanish". NTU student 4 proudly says: "I have Spanish friends now. I go to the gym with them and sometimes we play football". The experience of USAL student 1 does not differ substantially from that of her NTU counterparts: "University students go out almost every day. I join them sometimes and we go to the disco or to the pub".

A notable $40 \%$ of USAL and just a slightly higher $42.5 \%$ of NTU students state that they do not usually go out with members of their own culture (i-6). Nor do their answers exhibit a relevant difference regarding their preference to socialise with either Erasmus or local students (i-5): USAL 2.88; NTU 2.67. Not surprisingly, the $\mathrm{T}$ test results reveal that NTU students who speak a third language seem to prefer to go out, mix, and converse with other Erasmus students with whom they may thrive in a rich multilingual environment [T test 3,019; df 38; Sig. 0,005].

One of the most noticeable findings of our analysis is the fact that students from neither university show significant discrepancies in their socialisation patterns during their stay abroad.

Concerning their general perceptions during their Erasmus experience, which include aspects such as their self-image, feelings of homesickness, or level of integration, as reflected in table 2, the item that the two groups valued most highly deals with learning about and accepting local customs regarding aspects such as eating habits, timetables, celebrations, use of degrees of formality and informality in diverse situations, etc. (NTU 4.35; USAL 4.20). The fact that $95 \%$ of NTU student and $86.6 \%$ of their USAL counterparts assigned this item (i-1) the highest score of the scale speaks for itself. In this instance, $T$ test results add a further statistically 
Table 2. Perceptions. Percentage of frequency of NTU and USAL students' perceptions during their Erasmus experience (NTU $n=40$, USAL $n=30$ )

\begin{tabular}{|l|c|c|c|c|c|c|c|c|}
\hline & NAT & 1 & 2 & 3 & 4 & 5 & Average & $\begin{array}{c}\text { Standard } \\
\text { Deviation }\end{array}$ \\
\hline $\begin{array}{l}\text { 1. I am learning a lot } \\
\text { about the local habits and }\end{array}$ & NTU & 0 & 2.5 & 2.5 & 52.5 & 42.5 & 4.35 &, 662 \\
\cline { 2 - 9 } $\begin{array}{l}\text { I accept them for what } \\
\text { they are }\end{array}$ & USAL & 0 & 0 & 13.3 & 53.3 & 33.3 & $\mathbf{4 . 2 0}$ &, 664 \\
\hline $\begin{array}{l}\text { 2. I could definitely live in } \\
\text { this country in the same } \\
\text { way they do here, without } \\
\text { having any problems }\end{array}$ & USAL & 6.7 & 6.7 & 26.7 & 33.3 & 26.7 & $\mathbf{3 . 6 7}$ & 1.155 \\
\cline { 4 - 10 } $\begin{array}{l}3 . \quad \text { As an Erasmus } \\
\text { student I see myself as } \\
\text { a representative of my } \\
\text { home culture }\end{array}$ & NTU & 2.5 & 2.5 & 20 & 47.5 & 27.5 & $\mathbf{3 . 9 5}$ &, 904 \\
\cline { 2 - 10 } & USAL & 6.7 & 6.7 & 53.3 & 26.7 & 6.7 & $\mathbf{3 . 2 0}$ &, 925 \\
\hline $\begin{array}{l}\text { 4. I knew a lot about } \\
\text { the host country before I } \\
\text { came here }\end{array}$ & NTU & 5 & 15 & 15 & 45 & 20 & $\mathbf{3 . 6 0}$ & 1.128 \\
\cline { 2 - 10 } & USAL & 13.3 & 26.7 & 26.7 & 26.7 & 6.7 & $\mathbf{2 . 8 7}$ & 1.167 \\
\hline $\begin{array}{l}\text { 5. In the beginning I felt } \\
\text { like I wanted to return } \\
\text { home again }\end{array}$ & NTU & 42.5 & 20 & 10 & 15 & 12.5 & $\mathbf{2 . 3 5}$ & 1.477 \\
\cline { 2 - 9 } & USAL & 33.3 & 13.3 & 13.3 & 6.7 & 33.3 & $\mathbf{2 . 9 3}$ & 1.721 \\
\hline
\end{tabular}

significant finding which reveals that USAL students who speak a third language consider that they are learning from the local habits and they accept them for what they are more than their Spanish peers who only know or are learning a foreign language [T test 2,542; df 28; Sig. 0,017]. Once again, the sojourners' voices in the following excerpts both embody and situate the preceding data, making them come alive and be filled with meaning in very concrete everyday situations. For example, NTU student 2 affirms: "I understand the culture better. I got used to the Spanish way of life very soon". NTU student 3 refers to a specific step he took in order to adapt to his new environment: "As soon as I arrived, I changed my eating timetable". USAL student 4 testifies to a change in her frame of mind and in specific behaviour: "I learned to live as they did. I used their timetable to do things on time. I had to be open-minded and tried not to compare everything to what is done in Spain".

Even beyond the acceptance of cultural habits which differ from those of their home country, the clearest evidence of their positive perception of the host country lies in the results of the second item where students were asked whether 
APPROACHING ERASMUS STUDENTS' INTERCULTURAL COMMUNICATIVE COMPETENCE THROUGH THEIR ...

they could definitively live in the country of their Erasmus placement in the same way as locals do, with a significant $90 \%$ of NTU students and $86.6 \%$ of their USAL counterparts assigning positive values to this item.

The following testimonies of students from both groups express that they would be happy to live in the host country and confirm the quantitative data gathered in previous studies, where the attitude dimension proved to be valued most positively by both cohorts of students (Gutiérrez, Durán and Beltrán 2015; Durán et al. 2016). NTU students 2 and 3 share respectively their newly gained confidence after having decided to embrace the Spanish way of life instead of constantly assessing it against their British background: "I have learned to live like a Spanish citizen, particularly regarding their timetables and eating habits and the ways of organizing their meals"; "I now fully understand the Spanish lifestyle and I consider that I am equipped and ready to work in Spain”. USAL student 5 lists what for her had been initially striking differences and which are not any longer perceived as obstacles or judged as negative aspects: "After living for eight months in Nottingham, I can say that although English people eat mostly fast food, drive on the left, use pounds, measure distances in miles, have lunch at twelve and dinner at six, always drink tea, and wear summer dresses in winter, I could adopt these habits and live in the UK because I love the country".

Item three values the students' self-perception as representatives of their own culture, which requires them to ponder their overall experience in terms beyond their manifold learning "gains". Although the overall rating of the item is high in both groups of students (NTU 3.95; USAL 3.20) they exhibit differences worth noticing for, whereas $75 \%$ of NTU students assign the highest values to this item, only 33 ' $4 \%$ of USAL students give it the highest scores. When students look back to the beginning of their placement, $65 \%$ of NTU students reiterate that they were knowledgeable about the host country versus only 33' $4 \%$ of USAL students (i-4). These data attest to the fact that it is also NTU students who have been in the host country before this university placement in a much greater proportion than USAL beneficiaries of the Erasmus grant, for $74 \%$ of whom this placement was their first time abroad for longer than a month. These data seem to be fully consistent with the percentage of USAL students who wanted to return home at the beginning of their stay ( $40 \%$ ) as against only 27 '5\% of NTU students (i-5). After a $\mathrm{T}$ analysis, the two items in table 2 which show a significant statistical difference between NTU and USAL students are item number 3, concerning Erasmus students' self-image as representatives of their home culture [T test 3.401; df 68; Sig. 001] and item number 4, dealing with their previous knowledge about the host country [T test 2.653; df 68; Sig. 010]. 
Table 3. Intercultural lessons. Percentage of frequency of NTU and USAL students' ICC lessons during their Erasmus experience (NTU n=40, USAL n=30)

\begin{tabular}{|l|c|c|c|c|c|c|c|c|}
\hline & NAT & $\mathbf{1}$ & $\mathbf{2}$ & $\mathbf{3}$ & $\mathbf{4}$ & $\mathbf{5}$ & Average & $\begin{array}{c}\text { Standard } \\
\text { Deviation }\end{array}$ \\
\hline $\begin{array}{c}\text { During my stay in the host } \\
\text { country I found out that it } \\
\text { is very important to: }\end{array}$ & & & & & & & \\
\hline $\begin{array}{c}\text { A) Learn the language of } \\
\text { the country }\end{array}$ & NTU & 0 & 2.5 & 5 & 5 & 87.5 & 4.78 &, 660 \\
\cline { 2 - 10 } & USAL & 0 & 0 & 0 & 20 & 80 & 4.80 &, 407 \\
\hline $\begin{array}{c}\text { B) Get information about } \\
\text { the differences between } \\
\text { cultures beforehand }\end{array}$ & NTU & 0 & 2.6 & 15.4 & 48.7 & 33.3 & 4.13 &, 900 \\
\cline { 2 - 10 } $\begin{array}{c}\text { C) Be open-minded and } \\
\text { socialise a lot with } \\
\text { others }\end{array}$ & 0 & 0 & 33.3 & 20 & 46.7 & 4.13 &, 767 \\
\cline { 2 - 10 } & USAL & 0 & 0 & 7.5 & 17.5 & 75.5 & 4.68 &, 616 \\
\hline $\begin{array}{c}\text { D) Change my own national } \\
\text { customs to blend in } \\
\text { with the locals }\end{array}$ & NTU & 2.6 & 15.4 & 25.6 & 35.9 & 20.5 & $\mathbf{3 . 5 6}$ & 1,071 \\
\cline { 2 - 10 } & USAL & 6.7 & 20 & 33.3 & 20 & 20 & $\mathbf{3 . 2 7}$ & 1,202 \\
\hline
\end{tabular}

What we would like to highlight from table 3 is that at the end of their placement, both groups of students reached the conclusion that learning the target language (i-A) is their first and foremost priority (NTU 4.78; USAL 4.80), something which is consistent with the findings of our previous study (Durán et al. 2016). A proficient command of the L2 is what they identify as their utmost priority as well as a factor that definitely favours their ICC. Their temporary immersion experience is precisely what can help them bridge the gap between curricular requirements and a use of the language beyond their academic confine. The two cohorts also highly rank being open minded and socialising with others (NTU 4.68; USAL 4.73), which entail, again, the possibility to further their linguistic and cultural experience through real communication. During their stay, they also realise that the more information they have about the differences between cultures prior to their sojourn (about the people, traditions, religion, art, etc.) the better equipped they will be to make the most of their intercultural experience (NTU 4.13; USAL 4.13). They are ready to change their cultural behaviour while in the host country so as to get to blend in with the locals (NTU 3.56; USAL 3.27). This difference between NTU and USAL students reflects the paradoxical fact that while NTU students show a greater readiness to 
APPROACHING ERASMUS STUDENTS' INTERCULTURAL COMMUNICATIVE COMPETENCE THROUGH THEIR ...

blend in with the locals at the same time they claim to act as representatives of their own culture to a greater extent than their USAL counterparts (table 2, i-3).

The results of the T test reveal the following statistically significant differences in each of the four items of table 3. In option A, there are significant statistical differences between the NTU students that do not speak a third language and those that do. The first group highlights the importance of learning the target language more that the second group [T test 2,187; df 30; Sig. 0,037]. In option B there are significant statistical differences between those students from USAL that had been in a foreign country before and those for whom their Erasmus placement is their first time abroad. Thus, USAL students whose first experience abroad is the Erasmus placement consider that it is very important to get information about the differences between host and target country [T test 2,834; df 19,909; Sig. 0,01]. In options C and D there are significant statistical differences between the USAL students who are speakers of a third language and those that only speak a language in addition to their own: the former have realised that it is very important to be open minded and socialise [T test 2,822; df 12,298; Sig. 0,015] and they have also found out that it is very important to change their own customs in order to get integrated in the host country [T test 2,975; df 27,094; Sig. 0,006].

\section{CONCLUSION}

Having adopted Byram's work on ICC (1997; Byram, Gribkova, and Starkey 2002) as a compass of sorts, our approach to the impact of Erasmus students' placements on the development of their ICC has also been based on a conceptualisation of students as "liquid strangers" (Dervin 2007) and "self-reflective, intentional agents", immersed in a "fluid and complex system of social relations, activities, and multiple micro- and macro contexts" (Ushioda 2009: 20).

After analysing NTU and USAL Erasmus students' socialisation patterns, we can conclude that, during their stay abroad, students from neither university show major discrepancies in the three broad categories under scrutiny: everyday interactions, self and other perceptions, and intercultural lessons, although some noteworthy differences have emerged.

Regarding the first category, concerning everyday interactions, their answers to the questionnaires and their interviews reflect a myriad of interactions in their host communities. The richness of such a plethora of interactions is largely due to the fact that they take place in diverse contexts as Erasmus students tend to live with local students and engage in different types of activities, which may include everyday familiar things at home or outdoor activities such as 
playing football, going to the gym or shopping. Although their mother tongue and culture are still present and are immediately available through computer-mediated communication, to which students frequently resort, a significant percentage of both groups of students confirm that they use the target language most of the time and socialise with local and other Erasmus students. And despite their placements being limited in time, therefore "liquid" and set in a third or symbolic space, the rich and varied experiences which students engage in within their communities of practice, allows them to forge long standing personal relationships and to broaden the boundaries of their identity. This cannot happen unless students develop a stronger sense of ICC during their linguistic and cultural engagement in the course of their placements.

As for the second category, self and other perceptions, the two groups value most highly learning about and accepting local customs. Both share their perception that they could definitively live in the country of their Erasmus placement, which seems to be the clearest evidence of their ICC perceived outcomes. Significant differences between both groups can be observed in the Erasmus students' self-image as representatives of their home culture and in their previous knowledge about the host country. In the first case, NTU students claim to act as representatives of their culture to a greater extent than their USAL counterparts even if the former show a greater readiness to blend in with the locals.

The answers to the third category show that at the end of their placement, all of the students agreed that learning the target language was their priority, not only because it is a curricular requirement but also because they realised it is crucial for the development of their ICC, which is not incompatible with avoiding the risk of equating the students' time abroad to only an intensive foreign language training programme. This is also consistent with the fact that the two cohorts rank very highly being open minded and socialising with others, that is, making their sojourn meaningful through real communication, as indeed they also realise that their ICC can be greatly improved by being knowledgeable of language and culture idiosyncrasies beforehand.

In short, despite some differences both between and within the two groups, we can still affirm that NTU and USAL students attach an equivalent and almost unanimously favourable meaning to the Erasmus placements, share the same aims and expectations and can be identified as belonging within a distinctive community of speakers in a foreign country which has been aptly labelled "international Erasmusland" (Beaven 2012: 221; Coleman 2015).

A whole pre, during and post-placement approach can help to make their study abroad even more meaningful. Prior to their placement, ICC induction 
APPROACHING ERASMUS STUDENTS' INTERCULTURAL COMMUNICATIVE COMPETENCE THROUGH THEIR ...

schemes may bring together incoming and outgoing students to exchange their experience and concerns. During their placement, major benefits may be drawn from even a greater involvement of students in activities within the host academic community in tandem schemes as well as from other ways of social engagement available at local level. After their placement, opportunities to reflect and report on their stay abroad could help ground the learned lessons and share them with prospective Erasmus students. Thus, the identification of interaction factors which may be conducive to ICC during study abroad schemes yields relevant consequences for the design of activities aimed at equipping tertiary students to become competent intercultural agents.

\section{REFERENCES}

Baker, W. 2016. "Culture and Language in Intercultural Communication, English as a Lingua Franca and English Language Teaching: Points of Convergence and Conflict". The Cultural and Intercultural Dimensions of English as a Lingua Franca. Eds. P. Holmes and F. Dervin. Bristol, Buffalo: Multilingual Matters. 70-89.

Bauman, Z. 2007. Identity. Cambridge: Polity.

Beaven, A. 2012. An exploration of cross-cultural adaptation in the context of European student mobility. Unpublished Ph. D. thesis, University of Warwick: United Kingdom.

Beaven, A. and C. Borghtetti. 2016. "Interculturality in study abroad". Language $\varepsilon$ Intercultural Communication 16 (3): 313-317. http://doi.org/10.1080/14708477.20 16.1173893.

Borghetti, C., Beaven, A. and R. Pugliese. 2015. "Interactions among future study abroad students, exploring potential intercultural learning sequences". Intercultural Education 26 (1): 31-48. http://doi.org/10.1080/14675986.2015.993515.

Bracke, A. and S. Aguerre. 2015. "Erasmus students: Joining communities of practice to learn French?" Social interaction, identity and language learning during residence abroad. Eds. R. Mitchell, N. Tracy-Ventura and K. McManus. Amsterdam: Eurosla Monographs Series, 4. 139-168.

Buynsters, M. L. 2012. Together with People from Abroad, We Open Borders. Unpublished Ph. D. thesis. University of Utrecht: Netherlands.

Byram, M. 1997. Teaching and Assessing Intercultural Communicative Competence. Clevedon: Multilingual Matters.

Byram, M. 2000. "Assessing intercultural competence in language teaching". Sprogforum 18: 8-13. 
Byram, M. 2012. "Conceptualizing intercultural (communicative) competence and intercultural citizenship". The Routledge Handbook of Language and Intercultural Communication. Ed. J. Jackson. Oxon and New York: Routledge. 85-97.

Byram, M., Gribkova, B. and H. Starkey. 2002. Developing the Intercultural Dimension in Language Teaching. A Practical Introduction for Teachers. Strasbourg: Council of Europe.

Byram, M. and G. Zarate. 1997. The Sociocultural and Intercultural Dimension of Language Learning and Teaching. Strasbourg: Council of Europe.

Coleman, J. 1998. "Evolving intercultural perceptions among university language learners in Europe". Foreign Language Learning in Intercultural Perspective. Eds. M. Byram and M. Fleming. Cambridge: Cambridge University Press. 45-75.

Coleman, J. 2015. "Social circles during residence abroad: What students do, and who with". Social interaction, identity and language learning during residence abroad. Eds. R. Mitchell, N. Tracy-Ventura and K. McManus. Amsterdam: Eurosla Monographs Series, 4. 33-52.

Deardorff, D. K., ed. 2009. The SAGE Handbook of Intercultural Competence. Los Angeles, London, New Delhi, Singapore, Washington DC: SAGE.

Dervin, F. 2007. "The Erasmus experience: halcyon days of hypermodernity?" Yli rajojen. Erasmus Eurooppalaista korkeakoulutusta rakentamassa. Eds. M. Airas and V. Zenkner. Helsinki: Center for International Mobility CIMO Libris Oy. 116-125.

Dervin, F. 2011. "A plea for change in research on intercultural discourses: A liquid approach to the study of the acculturation of Chinese students". Journal of Multicultural Discourses 6 (1): 37-52.

Durán, R., Gutiérrez, G., Beltrán, F. and F. Martínez. 2016. "The Impact of an Erasmus Placement in Students' Perception of their Intercultural Communicative Competence". Journal of Intercultural Communication Research 28 (4): 738770. http://doi.org/10.1080/17475759.2016.1186721.

European Commission. 2015. "The new EU programme for Education, Training, Youth, and Sport for 2014-2020". <http://ec.europa.eu/programmes/erasmusplus/node_en>. (Accessed 15 March 2017)

Gautier, R. and J. P. Chevrot. 2015. "Social networks and acquisition of sociolinguistic variation in a study abroad context: A preliminary study". Social interaction, identity and language learning during residence abroad. Eds. R. Mitchell, N. Tracy-Ventura and K. McManus. Amsterdam: Eurosla Monographs Series, 4. 169-184. 
APPROACHING ERASMUS STUDENTS' INTERCULTURAL COMMUNICATIVE COMPETENCE THROUGH THEIR ...

Gutiérrez, G., Durán, R. and F. Beltrán. 2015. "Identifying students' intercultural communicative competence at the beginning of their placement: towards the enhancement of study abroad programmes". Intercultural Education 26 (1): 73-85. http://doi.org/10.1080/14675986.2015.997004.

Holliday, A. 2016. "Differences and awareness in cultural travel: negotiating blocks and threads". Language \& Intercultural Communication 16 (3): 318331. http://doi.org/10.1080/14708477.2016.1168046.

Kinginger, C. 2009. Language Learning and Study Abroad: A Critical Reading of Research. New York: Palgrave/Macmillan.

Kinginger, C. 2015. "Student mobility and identity-related language learning". Intercultural Education 26 (1): 6-15. http://doi.org/10.1080/14675986.2015.992199.

Kramsch, C. 2009. The Multilingual Subject: What Foreign Language Learners Say about their Experience and Why it Matters. Oxford: Oxford University Press.

McManus, K., Mitchell, R. and N. Tracy-Ventura. 2014. "Understanding insertion and integration in a study abroad context: The case of English-speaking sojourners in France". Revue Français of Linguistique Appliquée 19 (2): 97-116.

Méndez, $\mathrm{M}^{\mathrm{a}}$ del C. and $\mathrm{M}^{\mathrm{a}}$ L. Pérez. 2011. "Multicultural Teamwork as a Source of Experiential Learning and Intercultural Development". Journal of English Studies 9: 145-163. http://doi.org/10.18172/jes.169.

Penman, C. and S. Ratz. 2015. "A module-based approach to foster and document the intercultural process before and during the residence abroad". Intercultural Education 26 (1): 49-61. http://doi.org/10.1080/14675986.2015.993529.

Risager, K. 1998. "Language Teaching and the Process of European Integration". Intercultural Perspectives in Language Learning. Eds. M. Byram and M. Fleming. Cambridge: Cambridge University Press. 242-254.

Risager, K. 2016. "Lingua Franca in a World of Migrations". The Cultural and Intercultural Dimensions of English as a Lingua Franca. Eds. P. Holmes and F. Dervin. Bristol, Buffalo: Multilingual Matters. 33-49.

Sáez-Hidalgo, A. and L. Filardo-Llamas. 2014. "3D in History of the English Language: Learning a L2 through history, context and cross-cultural experiences". Journal of English Studies 12: 127-147. http://doi.org/10.18172/ jes. 2827.

Smolcic, E. 2013. "Opening up the world'? Developing interculturality in an international field experience for ESL teachers". Social and Cultural Aspects of Language Learning in Study Abroad. Ed. C. Kinginger. Philadelphia: John Benjamins. 75-99. 
Teichler, U. 2015. "The impact of temporary study abroad". Social interaction, identity and language learning during residence abroad. Eds. R. Mitchell, N. Tracy-Ventura and K. McManus. Amsterdam: Eurosla Monographs Series, 4. 15-32.

Ushioda. E. 2009. "A person-in-context relational view of emergent motivation, self and identity". Motivation, language identity and the L2 self. Eds. Z. Döryei and E. Ushioda. Bristol: Multilingual Matters. 215-228. 